\title{
Empathy and University Students' Business Startups: The Moderating Role of Experiential Learning
}

\author{
Maxwell Olokundun*, Guleduwa Joyce Dishon, Ayodotun Stephen Ibidunni, Mercy Ogbari \\ Department of Business Management, Covenant University, Nigeria
}

Received July 26, 2020; Revised August 25, 2020; Accepted September 29, 2020

\section{Cite This Paper in the following Citation Styles}

(a): [1] Maxwell Olokundun, Guleduwa Joyce Dishon, Ayodotun Stephen Ibidunni, Mercy Ogbari, "Empathy and University Students' Business Startups: The Moderating Role of Experiential Learning," Universal Journal of Educational Research, Vol. 8, No. 12, pp. 6415-6428, 2020. DOI: 10.13189/ujer.2020.081207.

(b): Maxwell Olokundun, Guleduwa Joyce Dishon, Ayodotun Stephen Ibidunni, Mercy Ogbari (2020). Empathy and University Students' Business Startups: The Moderating Role of Experiential Learning. Universal Journal of Educational Research, 8(12), 6415-6428. DOI: 10.13189/ujer.2020.081207.

Copyright $\bigcirc 2020$ by authors, all rights reserved. Authors agree that this article remains permanently open access under the terms of the Creative Commons Attribution License 4.0 International License

\begin{abstract}
Many universities in developing economies are now recognising the role of the university in entrepreneurship education and development of key entrepreneurial skills by students. Consequently many universities in these nations are expanding the curriculum contents of entrepreneurship courses and training to help students develop these key skills. As a student entrepreneur it is important that students are taught the capabilities of instantly thinking outside the box which also involves empathising in order to visualize the various outcomes. Often from these challenges a student entrepreneur can take advantage of opportunities, if they are taught how to engage empathy to clearly see them. Therefore, the goal of this paper was to examine the influence of empathy among university students as a determinant of creation of successful and innovative students' start-ups. The moderating role of experiential learning was also assessed. To achieve this goal, a sample size of 357 students of Covenant University in Nigeria, was used. The data collected were analysed by means of regression analysis and Hayes process macro. The result showed that empathy has positive significant effect on students' start-ups among university students $(\mathrm{p}<0.05)$ and experiential learning moderated the relationship between empathy and students start-ups among university students. Based on the findings the study concluded that university managers and other stakeholders in developing countries may expand entrepreneurship training and education curriculum contents based on the development of empathy as an entrepreneurial skill. The findings also indicated that moderate levels of experiential learning
\end{abstract}

activities are required to achieve best results. Therefore, university managers and other stakeholders may expand the curriculum of entrepreneurship training and education regimes to cover the development of empathy as an entrepreneurial skill. It is important to state that empathy is an entrepreneurial skill that can be developed hence, teaching empathy as a theme targeted at the creation of creative start-ups is considered favourable in this regard.

Keywords Empathy, Business Start-ups, University students

\section{Introduction}

Entrepreneurship education in Nigeria, among other things, aims to provide the awareness, skills and inspiration to students in tertiary institutions to promote entrepreneurial success through a variety of projects. By developing new goods and services, entrepreneurs minimize dependency on outdated technology and thus improve and simplify everyday life. Entrepreneurship education helps students of all social backgrounds think beyond the box and develop unique talents and skills. It provides opportunities, promises social inclusiveness, builds confidence and stimulates the economy. The effect of entrepreneurship education in Nigeria is a good one considering that the entrepreneurship curriculum allows learners create and support social change.

Nevertheless, a germane entrepreneurial skill that should be taught in order to create a positive change in the 
entrepreneurial space is empathy (Chander, 2017). Success stems from ideas, and in order to have those ideas created, heard and discussed a student entrepreneur must possess empathy. Therefore, to succeed as a start-up, a student entrepreneur must be taught to take on what others say and see things from a different perspective, as being in their shoes. A student entrepreneur must be taught to appreciate, understand and share those feelings of others. Empathy is a hard business skill that's absolutely critical to the bottom line. This empathy must be directed at customers, partners and all a student entrepreneur is working with. Greater and deeper relationships are built upon feelings of trust hence, in order to have long-lasting and genuine relationships a start-up must engage empathy. Student start-ups often face dilemmas of needing to change or alter the product, the message, the goal, the idea, the team, the concept, the brand, the voice among many other aspects (Ooi \& Ahmad, 2012). Start-ups are constantly changing, adapting and learning as they face new situations, problems or opportunities. As a student entrepreneur it is important to have the capabilities of instantly thinking outside the box which also involves empathising in order to visualize the various outcomes. Often from these challenges a student entrepreneur can take advantage of opportunities, if they are able to engage empathy to clearly see them. Therefore having empathy is such an important quality for a student entrepreneur.

However, the question is, can empathy be taught and learn as an entrepreneurial skill? As Heick (2015) argues, empathy represents concern towards others and is no more instinctively present in some individuals than in others. It is an ability that can be learned and nurtured in a positive learning environment. To this end, Kutlu and Coskun (2014) examined the role and performance of empathy in the learning process; the relation between management functions and empathy and their effect on the academic performance in basic vocational training students was also assessed by Cid-Sillero, et.al (2018). while more recently, the role played by empathy in industry, with focus on core skill of entrepreneurial competency and mind set, was explored by Korte, et.al (2018). Most extant studies related to the subject of this research have largely ignored the role of empathy in entrepreneurship education with emphasis on motivating students' start-ups particularly in the university setting. This is particularly relevant to developing nations where entrepreneurship education is still at the formative stage in most universities Therefore, the goal of this paper is to examine the influence of empathy development among university students as a determinant of creation of successful and innovative students' start-ups.

\section{Theoretical Background}

\section{Entrepreneurship Education}

Education in entrepreneurship as any pedagogical program is associated with inculcating entrepreneurial skills and learner qualities (Zapeda, 2013). Entrepreneurship education is the scope of lectures, curricula, and programs aimed at providing students with the requisite entrepreneurial skills, knowledge, and skills to pursue an entrepreneurial career (Zhou, et.al, 2012). Entrepreneurs were assumed to be individuals with peculiar genes that emerge as a result of genetic inheritance, but this theory has been demystified on the basis that every person has the potential to become an entrepreneur through the educational process (Ubpgu, 2014). Most concepts of entrepreneurship education accept that one of the key goals is to instill in learners entrepreneurial skills that should culminate in entrepreneurial actions and practice (Saeid, et.al, 2014). Knowledge, skills and competencies are two main terms closely associated with education as a definition (Purcarea, 2012). Therefore a comprehensive definition of entrepreneurship education should incorporate information and skills as process outcomes (Piperopoulos \& Dimov, 2014). This study will therefore follow the concept of entrepreneurship education proposed by Alberti Sciascia and Poli (2004), which defined entrepreneurship education as the organized formal communication of entrepreneurial skills, consisting of the skills and mental knowledge employed by individuals towards the expression of entrepreneurial actions and practice.

It can be argued that education and learning about entrepreneurship need to reflect the phase that entrepreneurs go through by focusing on practice, real-world experiences and reflection (Penaluna, et.al, 2012). Courses based on skills and knowledge growth indicate that students are more likely to engage in entrepreneurship (Nabi et al. 2017). In response to conventional courses on entrepreneurship, Neck and Greene (2011) emphasize that education on entrepreneurship should concentrate on how to conduct, foresee and generate in an unknown future. Entrepreneurship course content would concentrate on the process of learning entrepreneurial skills and mind-sets. With this in mind, there has been a shift from teaching conventional curriculum content to a more holistic approach, where the course content is more focused on developing entrepreneurial mind-sets and behaviors (Olorundare and Kayode, 2014). It has also been argued that empathy is a key skill for entrepreneurs who want to build effect thus teaching empathy is a possible future in extending a program's content reach. Educating empathy, however, is about educating the students, not material. This is important because how they feel about the incoming knowledge will ultimately determine how useful it is to them. This emphasises the place of experiential learning in entrepreneurship education.

\section{Experiential Learning in Entrepreneurship Education}

The creative learning scenarios for entrepreneurship 
students provide them with the ability, in their own professional and personal lives, to apply the principles and skills of a course to real-life problems and circumstances. This approach contributes to the identification of patterns in problems and possible solutions. In the future, students will draw on an abundance of examples and knowledge of similarities between the issues and approaches that they have helped to create, because they face similar problems. All this preparation will help students to improve their knowledge base (Helle, Tynjälä, \& Olkinuora 2006). Experiential learning research shows that the participation in an experiential learning class enhances the student's intrinsic motivation to learn through classrooms (Helle, Tynjälä, Olkinuora \& Lonka, 2007). One way to encourage experience learning is to motivate learners throughout the learning process by allowing them a degree of autonomy - students have to lead in finding and applying solutions to problems, and throughout their own learning process make multiple choices (Svinicki \& McKeachie, 2014). The emotional experiences of students when they learn sometimes are overlooked, but recent psychological research illustrates the link between the way people feel emotion and knowledge; instead of behaving as separate systems, they go together. (Felten, Gilchrist, \& Darby, 2006). Students who engage in experience will encounter more emotional responses than a more traditional lecture-based classroom experience. For instance, considering a course on empathy in entrepreneurship education in which students are assigned the task of observing the customers in school's shopping mall. The students can observe elements of their challenges and frustrations. Furthermore, the students are likely to experience some (potentially strong) emotions as well - perhaps curiosity, confusion, joy, or even frustration or anger associated with customers relations and interactions at the business place. These emotions have the potential to enhance and strengthen the learning experience for the student.

\section{The Concept of Empathy}

Davis (2015) opines that empathy can be defined as the ability of understanding and sharing people's feelings, this a major skill for entrepreneurs that want to create value. A great number of people may have encountered this inclination at various occasions in their lives, sometimes it can be offering comfort to a friend who lost his job or did not get a promotion or maybe helping a neighbour get to his place of work because his car broke down, (Fairbairn, 2002). These are all actions done out of empathy, because we might have had similar experience sometimes in our life and we understand very well how the other person is feeling. Empathy is very important in every business dealings and a vital skill for maintaining sustainable success (Halpern, 2007). Entrepreneurs are always around people who need to be understood, either investors or shareholders, employees and also customers. At the point when an entrepreneur knows about the viewpoints and requirements of these individuals, the business will be pushed ahead and be reinforced (Dimov, 2010). The connection between the entrepreneur and the people around him gives the entrepreneur insights on how to run their business in the best and ideal way. Empathy also means the ability to recognize the feelings of others, the reason for the feelings, and the capacity to take an interest in the passionate experience of someone else without ending up with some portion of it (Keen, 2007). Empathy can be seen as the capacity to understand someone's feelings and at the same time conveying them. At the point when empathy is set up and utilized, it isn't likely for the entrepreneur to know precisely what someone else feels, notwithstanding, it is imperative for business people to endeavor to envision what the other individual is encountering.

Empathy and sympathy have been used interchangeably, Dees (2012) suggests that Sympathy is an emotional response, immediate and can mostly not be controlled, which overwhelms when a person sees himself in the person's position. While empathy is more of an attitude of life or a skill acquired, which is for the most part used to endeavor to connect with somebody, coming into contact with an individual, to impart and comprehend their encounters or emotions (Halpern, 2003). Ickes (2003) discussed that Empathy is also associated with related concepts, such as Compathy which is shared sentiments because of shared conditions. Empathy seen as understanding someone else's feelings through perspective taking. Mimpathy is replicating another person's feelings, without undergoing them yourself. Ickes (2003) also explained that Sympathy is an intentional reaction emotional. Transpathy is the emotional contagion, where somebody is tainted by another's feelings. Antipathy is a strong form of transpathy. However, the distinct attribute of empathy is the capacity to see the world through somebody eyes, which just means building up the capacity to envision what another person is considering and feeling in a given circumstance (Farahbod, 2014).

\section{Dimensions of Empathy and Entrepreneurship Education}

\section{Perspective Taking}

The taking of perspectives is an essential skill in almost every aspect of business. From sales and marketing to negotiations and workplace management, taking perspective is a key component for the success of a leader (Sophie \& Elisa 2018). Perspective taking essentially refers to the ability of thinking about someone else's point of view. Perspective taking eliminates all the emotional aspects and is solely concerned with how a situation is viewed by the other person. In a business setting, that is a very important distinction. Perspective taking involves 
understanding and predicting the desires, emotions and possible actions of another person (Davis, 2015). Although perspective taking is an innate ability, it is important to state that it can be sharpened and honed as a skill this is why it is relevant to the context of entrepreneurship education and university students' start-ups. By honing students' perspective taking skills, through entrepreneurship teaching student entrepreneurs are much more likely to come up with solutions that are acceptable to all parties (Prandelli et.al. 2016). By taking themselves out of the equation and by understanding customer's true motivations, student entrepreneurs can be taught to be better positioned to anticipate customers' responses and offer them suitable products.

\section{Emotional Domain}

Emotional empathy, also known as affective empathy or primal empathy, is the resulting subjective condition of emotional contagion. It is our automatic drive to respond adequately to the emotions of another (Achana \& kumara, 2018). That sort of empathy happens naturally, and often unintentionally. It was also regarded as the vicarious exchange of feelings. Controlling emotional empathy is a key skill that needs to be taught to student entrepreneurs when it comes to business decision making. Because healthy people are hard wired to experience emotional empathy, they often have little ability to control it (O'Boyle, Humphrey, Pollack, Hawver, \& Story, 2011). Therefore, being unable to control the strength and impact of other people's feelings on young people, particularly student entrepreneurs, can impair business decision-making at critical times (Mayer, Roberts \& Barsade, 2008). If a decision doesn't need to be made immediately, encouraging student entrepreneurs to use time wisely to focus on it is crucial. It is important to teach student entrepreneurs that holding off on a business decision is a sign of strength, not weakness - especially when emotions are involved. Teaching student entrepreneurs to institutionalize heuristics for the collection of information is a good way to ensure that business decisions are made in a timely fashion - neither too fast nor too late. It is also normal for student entrepreneurs to suffer from a lack of sufficient emotional empathy, so teaching them carefulness-based stress reduction can be extremely beneficial in getting emotional empathy back to its proper level and in making business-related decisions.

\section{Compassionate Domain}

Compassion not only knows and feels the suffering of the person, but moves towards support, if possible spontaneously. Heart feelings and brain thoughts are not contest (Doharty, 2018). They're very closely related. Compassionate Empathy acknowledges this inherent bond by assessing the emotional feeling of another human as well as his or her mental state (Dees, 2012). In the sense of university entrepreneurship education, it is important for student entrepreneurs to be trained to consider when a prospective client is unhappy with the aim of delivering relief by sharing the customer's emotional perspective and helping to provide a service or product that is acceptable. Student entrepreneurs should be taught that Compassionate empathy is basically using emotional intelligence to correctly respond to business situations.

\section{Business Start-up}

The word start-up refers to a company that is in its first stage of operation. Start-ups are created by one or more entrepreneurs who want to grow a product or service they believe there's a market for (Danish Agency for Science Technology \& Innovation (2016). Typically, these businesses start with high costs and small sales, which is why they are looking for funding from a number of sources such as venture capital. Start-ups are companies or projects based on a single product or service which the founders want to sell. Such companies usually lack a fully established business model and, more significantly, lack sufficient resources to move on to the next business process. (Castrogiovanni, 1996) Originally, most of those firms are owned by their investors. For more money, several start-ups end up turning to others - family, friends, and venture capitalists. California's Silicon Valley is known for its large venture capitalist culture and is a popular start-up destination, but is also widely considered the most demanding venue. Start-ups will take advantage of this seed capital to invest in research and build business plans (Grando, 2016). Market analysis helps to assess the need for a product or service, while a detailed strategic strategy outlines the company's mission statement, potential visions and priorities and management and marketing strategies (Shabangu, 2014). The most popular form of startup in the 1990s was dotcoms. Owing to a scramble among investors to gamble on the advent of these new types of companies, risk capital was extremely easy to acquire during this period. Sadly, due to big oversights in their underlying business plans such as a lack of sustainable sales, most of these internet start-ups ultimately went bust (Fontinelle, 2017). There were only a handful of companies that survived when the dotcom bubble exploded. Amazon and eBay are also examples of these companies. Within the first few years so many start-ups are struggling. This is why it's so critical this initial era. Entrepreneurs need to raise resources, develop a business model and business strategy, recruit key people, hammer out complex information with partners and investors, such as equity stakes, and prepare for the long term (Kenton, 2018). Some of today's most popular firms started out as start-ups - Facebook, Airbnb, Uber, SpaceX and Ant Financial — and gradually became 
publicly traded firms.

University students have more scope to focus on the successes and failures of launching a company in the sense of university entrepreneurship education. This is in line with the study conducted by Shirokova, Osiyevskyy and Bogatyreva (2015), who showed that students role in the start-ups of businesses in countries as regards training new generations of entrepreneurs has been increasingly recognized. The founding of Facebook at Harvard and Michael Dell, who established Dell Computers, founded several of the major technology disruptions at University of Texas at the University of Austin in his dorm. University entrepreneurs like Mark Zuckerberg Therefore, university entrepreneurship education provides students with a good platform in which to communicate their thoughts and ideas about an entrepreneurial future through creative practices.

\section{Dimensions of Student Start-ups and Entrepreneurship Education}

\section{Ideation}

Pam (2013) defined an idea as a viable corporate concept that can be turned into a business. Long (2010) has concluded that it is important either to find a business idea or to create a viable business concept from a business point of view as an intentional action. Arenius and De Clercq (2005) concluded that the level of information gained by the entrepreneur improves the potential of an idea to develop, execute and communicate new business ideas. Pam (2013) defined a business idea as being feasible and workable in an enterprise. Long (2010) argued that the development, from an entrepreneurial perspective, of ideas as intentional action would require either a business idea to be found or a sustainable business idea to be created over a certain period of time. Arenius and Declerq (2005) concluded that the quality of information provided by the entrepreneur enhances the ability to generate an idea. Consequently, students are developing creative ideas in the sense of an entrepreneurship program as asserted by Morais (2001) and they can generate innovative and workable ideas through the teaching of entrepreneurship...

\section{Business Plan Writing}

Baker et al. (1993) notes that a business plan is a road map that outlines an organisation's point of reference, direction and future. We argued that both start-ups and large firms are using business plans. The use of business strategies increases the prospect of survival and development of the company, as well as reduces the chances of failure (Perry, 2001). Armstrong and Mahmood (2008) have indicated that the actual goal of a business planning is that entrepreneurs with implications for business growth are able to develop correct attitudes and motivations. Business planning was described by Brinckmann, Grichnik and Kapsa (2010) as a process involving entrepreneurial intentions and behavior to ensure the survival, prosperity and growth of an enterprise; Delmar and Shane (2004) argued that a well-written business plan refers to the plans of a company which needs investment capital from financial institutions, venture capitalists or angel investors.

Thus, White, Hertz and D'Souza (2011) propose that students at universities should conduct business planning processes involving an informal analysis of certain key aspects of business performance, in the sense of entrepreneurship education. It is important in particular as it is obvious that the drafting of a student's business plan reveals students' goals and business expectations (Honig \& Karlsson, 2004). The dedication of students to entrepreneurship can be inspired by formalizing goals in a business plan.

\section{Venture Creation}

The creation of a new ideas or technology is a phase in which investors are able to succeed and attract (Khajeheian, 2013).

It is the cycle between starting a business and selling for the first time. The venture creation system includes the maker, the creating process, creating new values, the close environment and the remote environment in five components. Venture creation is therefore seen as a multidimensional construction, with a close relation between the creator, the creation process and the creation of new values. (Becker, et.al 2015).

It means that three layers or phases of research are necessary to contribute to the decision-making of an organization. This includes an analysis of the customer (contractor), an environmental analysis, and the strategic decision-making process for the best market solution (Salamzadeh \& Kesim, 2015). This is why the principle of venture development is important to university entrepreneurship because the aims of the entrepreneurship program can not be fully achieved except students through the series of measures necessary taught how to build new venture.

\section{Dimensions of Experiential Learning and Entrepreneurship Education}

\section{Concrete Experience}

In the sense of entrepreneurship education, Knowles, Holton, and Swanson (2011) have mentioned that through simulations or entrepreneurial games, demos, the presentation of real world experiences and social problems the initial stage of Kolb's experiential learning model can be achieved. Gibb (2005) argued that 
entrepreneurs are perceived to be action-oriented individuals whose learning usually relies on experience. Therefore, learning from real-world experiences ensures students' full participation in fresh and practical experiences. Educators can also use creative methods, such as knowledge sharing, conceptual mapping and project-based learning, in the same context. The aim here will be to use correct pedagogies to inspire students to think and not to worry about business-related purposes.

\section{Reflective Observation}

Neck and Greene (2011) suggested that a reflective theory marks the transformation of perception through intention, suggesting that individuals consciously focus on their experiences and ideas. As Stevens and Kooper (2009) suggest through pedagogical methods such as reflection, class discussion and journal retention, the reflection assessment phase of the Kolb learning process can be achieved. These approaches offer a significant motivation for critical thinking, review of business education learning experiences and development of a course for the continued entrepreneurial growth of students.

\section{Abstract conceptualization}

The conceptualization of the abstract is the formation, based on reflection emerges from the stage of reflective evaluation of new ideas or modifies existing abstract conceptions (Zapeda, 2013). Abstract conceptualization is the most complex and enigmatic aspect of the Kolb model to be deciphered. It is because, as educators, we need to consciously blend the nuanced and divergent viewpoints of many of our students with those not presently articulated. It is a process of building links, but also of abstraction, to create deeper relations between otherwise distant experiences (Knowles, et.al, 2011).Take for example, in the context of entrepreneurship education how students learn about the frustrations of a customer who is not satisfied. They may not know why a customer might be frustrated with a product or service only after some understandings of theory in customer satisfaction. It takes the introduction of abstraction to understand that all businesses are created to satisfy a market or customer need/wants

\section{Active Conceptualisation}

Active conceptualisation the final stage of the Kolb's learning process can be carried out by writing business plans, developing a corporation, generating ideas, and finding opportunities (Neck \& Greene 2011). These activities serve as a bridge between business theory and practice as learners observe the business creation process through actual production and market delivery of new products and services (Stevens \& Cooper, 2009). Real life activities are considered valuable and effective in encouraging students to apply entrepreneurial skills in providing solutions to real life problems. In summary, the experiential theory of learning motivates the use of holistic approaches and pedagogies to inculcate skills and impart knowledge contained in entrepreneurship curricula.

\section{Hypothesis Development}

\section{Teaching Empathy and Student Start-ups: Moderating Role of Experiential Learning}

Experiential learning in entrepreneurial education increases the interest of students in entrepreneurship and business start-up activities. Arasti, Falavarjani and Imanipur (2012) studied this through the development of experiential learning strategies involving group projects, case studies and individual projects that promote new business creation ventures and the development of problem-solving skills among university students. In the same vein, the research by Malach and Malach (2014) indicates that skill training around business courses transmits practical, theoretical knowledge and incorporate best experienced learning experiences through active involvement in entrepreneurial activities. The authors concluded that starting and running a company is a unique and educational experience that allows students to apply extensive knowledge of entrepreneurship to a real business. Similarly, Canziani, Welsh, Hsieh and Tuller (2015) believed the entrepreneurial target is motivated by experiential and realistic training. Nevertheless, students with empathy may need help in explaining how the emotional experience is an important part of learning and thought. A significant point to note, as indicated by Piercy and Nigel (2011) and Bedawy (2017), is that high rates of experiential education, without any theoretical instructions, can detrimentally influence the learning process by giving students the opportunity to give critical thinking to their learning experiences. The relationship between experiential learning and student start-ups has been clearly identified in literature, especially at the university level. Therefore, it will be interesting to examine the role of empathy teaching in this relationship. Identifying this gap motivated the following hypothesis:

$\mathbf{H}_{\mathbf{0}}$ : experiential learning does not moderate the relationship between empathy teaching and student start-ups within the university context

\section{Methodology}

This study employed a descriptive research design to gather information from of the selected university (Olokundun et.al 2017). Descriptive research design was used to describe the characteristics of the population based on the relationship proposed between empathy and student 
startups in the university context. Survey was used as research method to enhance the determination of statistically significant results and the data collected were gotten through the administration of structured copies of questionnaire to $300-500$ level entrepreneurship students of Covenant University in Ogun State, Nigeria. This survey and research was approved and conducted under the auspices of the Covenant University Centre for Research and Innovation and Development (CUCRID). Covenant University is rated by Times Higher Education ranking as among the top 500 schools in the world and the leading institution in West Africa. It is also important to state that the institution is at the fore front of entrepreneurship education in the continent hence findings from this research can serve as a spring board for generalisation in the context of entrepreneurship education in the developing economies. The institution's embedded policy of graded practical entrepreneurial activities for the selected set of students which also involves business start-ups as a practical entrepreneurial activity also informed the choice of Covenant University.

The study population as gotten from the student affairs department of the institution is stated as 3240 students. The sample size was derived based on the recommendations of Barlett, Kotrlik and Higgins (2001). Therefore, at a confidence level of $95 \%$ and the error tolerance level of $5 \%$, the sample size used for this study was three hundred and fifty six (357). To this end, three hundred and fifty seven (357) copies of questionnaire were administered based on multistage sampling technique (Purposive, stratified and simple random sampling) to the sample respondents. Covenant University as an institution was purposively selected as well as the 300-500 level entrepreneurship students of the institution.

The students were stratified based on academic levels (300-500 level). Convenience sampling was employed to select respondents based from the three strata based on availability. Three hundred and thirteen (313) copies of questionnaire representing about $87.9 \%$ were recovered.
Hayes Process was used to test the moderating role of experiential learning as stated in the hypothesis. Empathy was assessed using a three-item measure. These items are: perspective taking; emotional domain and compassion domain. Business start-up was assessed using a three item measure. These items are; ideation; business planning and venture creation. Experiential learning was assessed based on a three item measure these are; concrete experience, reflective observation, abstract conceptualisation and active experimentation. Responses ranged by 5-point Likert scaling from 1= "Strongly disagree" to 5= "Strongly agree." Convergent reliability was conducted to assess the measurement model. The effect of the independent variable $\mathrm{X}$ (empathy) on the dependent variable $Y$ (business startup) can be considered to be moderated if its magnitude or path is dependent on a moderating variable $\mathrm{M}$ (experiential learning).

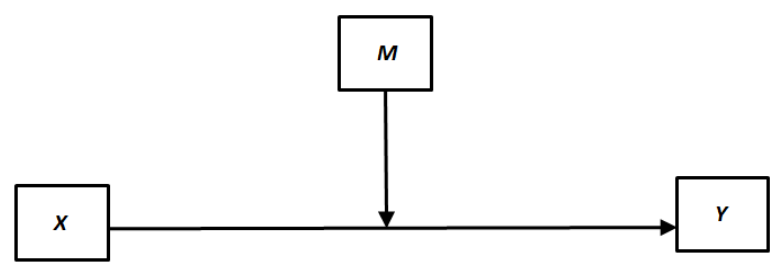

Figure 1. Conceptual Model showing the proposed Moderating Relationship

\section{Results}

\section{Measurement Model Evaluation}

For the assessment of measurement model, convergent reliability was conducted and Confirmatory Factor Analysis (CFA) was used for the assessment of composite reliability and the average variance extracted (AVE) of each construct using SPSS version 25 and excel package.

Table 1. Empathy

\begin{tabular}{|l|c|c|c|c|c|c|}
\hline & Loading & $\begin{array}{c}\text { Indicator } \\
\text { Reliability }\end{array}$ & $\begin{array}{c}\text { Error } \\
\text { Variance }\end{array}$ & $\begin{array}{c}\text { Composite } \\
\text { Reliability }\end{array}$ & AVE & No of Indicators \\
\hline Constructs and Indicators & $\mathbf{> 0 . 7}$ & & $<\mathbf{0 . 5}$ & $\mathbf{2 0 . 8}$ & $\mathbf{0 . 5}$ & \\
\hline \multicolumn{2}{|l|}{ Empathy } & & & 0.9030 & 0.8697 & 3 \\
\hline Perspective Taking (EMP1) & 0.8690 & 0.7552 & 0.2448 & & & \\
\hline Emotional Domain (EMP 2) & 0.8690 & 0.7552 & 0.2448 & & & \\
\hline Compassionate Domain (EMP 3) & 0.8710 & 0.7586 & 0.2414 & & & \\
\hline
\end{tabular}

All loadings are significant at $\mathrm{p}<0.05$

Source: Field Survey, (2019) 
EMP $01 \ldots 03$ consists of three empathy measures. Table 1 displays the reliability convergent and confirmatory factor analysis used to calculate the composite reliability of each construct and their average variance extracted (AVE). Both scale and measurement elements are important in the research instrument, according to Biggs, Brough and Barbor (2014) guidelines. Loading factor is higher than the 0.70 point, composite reliability is higher than 0.80 , and the AVE is above 0.50 . For the different constructs measures, the loading factor varied between 0.8690 and 0.8710 . The fitness of the measurements of the model is therefore valid.

EMP $01 \ldots 03$ consists of three business start-up measures. Table 2 displays the reliability convergent and confirmatory factor analysis used to calculate the composite reliability of each construct and their average variance extracted (AVE). Both scale and measurement elements are important in the research instrument, according to Biggs, Brough and Barbor (2014) guidelines. Loading factor is higher than the 0.70 point, composite reliability is higher than 0.80 , and the AVE is above 0.50 . For the different constructs measures, the loading factor varied between 0.8600 and 0.8720 . The fitness of the measurements of the model is therefore valid.

EMP $01 \ldots 04$ consists of four experiential learning measures. Table 3 displays the reliability convergent and confirmatory factor analysis used to calculate the composite reliability of each construct and their average variance extracted (AVE). Both scale and measurement elements are important in the research instrument, according to Biggs, Brough and Barbor (2014) guidelines. Loading factor is higher than the 0.70 point, composite reliability is higher than 0.80 , and the AVE is above 0.50 . For the different constructs measures, the loading factor varied between 0.8600 and 0.8720 . The fitness of the measurements of the model is therefore valid.

Table 2. Business Start Up

\begin{tabular}{|c|c|c|c|c|c|c|}
\hline & Loading & Indicator Reliability & $\begin{array}{c}\text { Error } \\
\text { Variance }\end{array}$ & $\begin{array}{l}\text { Composite } \\
\text { Reliability }\end{array}$ & AVE & No of Indicators \\
\hline Constructs and Indicators & $>0.7$ & & $<0.5$ & $\geq 0.8$ & $\geq 0.5$ & \\
\hline \multicolumn{4}{|l|}{ Business Startup } & 0.9033 & 0.8700 & 3 \\
\hline Ideation (ID1) & 0.8600 & 0.7534 & 0.2466 & & & \\
\hline Business Plan Writing (BP 2) & 0.8700 & 0.7569 & 0.2431 & & & \\
\hline Venture Creation (VC3) & 0.8720 & 0.7604 & 0.2396 & & & \\
\hline
\end{tabular}

All loadings are significant at $\mathrm{p}<0.05$

Source: Field Survey, (2019)

Table 3. Experiential Learning

\begin{tabular}{|c|c|c|c|c|c|c|}
\hline & Loading & Indicator Reliability & $\begin{array}{c}\text { Error } \\
\text { Variance }\end{array}$ & $\begin{array}{c}\text { Composite } \\
\text { Reliability }\end{array}$ & AVE & No of Indicators \\
\hline Constructs and Indicators & $\mathbf{> 0 . 7}$ & & $<\mathbf{0 . 5}$ & $\mathbf{2 0 . 8}$ & $\mathbf{2 0 . 5}$ & \\
\hline \multicolumn{2}{|l|}{ Experiential Learning } & & 0.9041 & 0.8710 & 4 \\
\hline Concrete Experience (BS1) & 0.8720 & 0.7604 & 0.2396 & & & \\
\hline Reflective Observation (BS 2) & 0.8670 & 0.7517 & 0.2483 & & & \\
\hline Abstract conceptualization & 0.8720 & 0.7604 & 0.2396 & & & \\
\hline Active Experimentation & 0.8690 & 0.7552 & 0.2448 & & & \\
\hline
\end{tabular}

All loadings are significant at $\mathrm{p}<0.05$

Source: Field Survey, (2019) 
Moderating Analysis

Model : 1

$\mathrm{Y}:$ STUDENT STARTUPS

$\mathrm{X}:$ EMPATHY

W : EXPERIENTIAL LEARNING

Sample

Size: 337

$* * * * * * * * * * * * * * * * * * * * * * * * * * * * * * * * * * * * * * * * * * * * * * * * * * * * * * * * * * * * * * * * * * * * * * * * * *$

OUTCOME VARIABLE:

STUDENT_

Model Summary

$\begin{array}{ccccccc}R & \text { R-sq } & \text { MSE } & \text { F } & \text { df1 } & \text { df2 } & \text { P } \\ .4410 & .1945 & .4403 & 26.8017 & 3.0000 & 333.0000 & .0000\end{array}$

Model

$\begin{array}{ccccccc} & \text { coeff } & \mathrm{se} & \mathrm{t} & \mathrm{p} & \text { LLCI } & \text { ULCI } \\ \text { CONSTANT } & .5536 & .6032 & .9177 & .3594 & -.6330 & 1.7401 \\ \text { EMPATHY } & .5301 & .1581 & 3.3533 & .0009 & .2191 & .8411 \\ \text { EXPERIEN } & .7244 & .1846 & 3.9248 & .0001 & .3614 & 1.0875 \\ \text { Int_1 } & -.1050 & .0457 & -2.2985 & .0221 & -.1949 & -.0151\end{array}$

Product terms key:

Int_1 : EMPATHY $x$ EXPERIENTIAL LEARNING

Test(s) of highest order unconditional interaction(s):

$\begin{array}{cccccc} & \text { R2-chng } & \text { F } & \text { df1 } & \text { df2 } & \text { p } \\ X * W & .0128 & 5.2833 & 1.0000 & 333.0000 & .0221\end{array}$

Focal predict: EMPATHY (X)

Moderating variable: EXPERIENTIAL LEARNING (W)

Conditional effects of the focal predictor at values of the moderator(s):

$\begin{array}{ccccccc}\text { EXP. } & \text { Effect } & \mathrm{se} & \mathrm{t} & \mathrm{p} & \mathrm{LLCI} & \text { ULCI } \\ 3.0000 & .2150 & .0573 & 3.7510 & .0002 & .1023 & .3278 \\ 3.6667 & .1450 & .0597 & 2.4285 & .0157 & .0276 & .2625 \\ 4.3333 & .0750 & .0755 & .9934 & .3212 & -.0735 & .2236\end{array}$

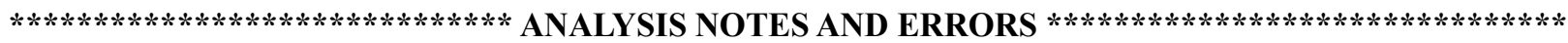

Level of confidence for all confidence intervals in output: 
To interpret the moderation effect, we will focus on the simple slopes, which are shown in output 2. Basically, the table shows us the outcomes of three diverse analysis: the analysis for empathy as a predictor of student start-ups;

(1) when experiential learning activities are low (3.0000);

(2) at the mean value of experiential learning activities (3.6667);

(3) when the value of experiential learning activities is high (4.333).

The emphasis is on the value of $b$ (denoted as Effect in the output), and its corresponding significance. Therefore, the three models can be interpreted as follows:

1. When experiential learning activities are low, there is a significant positive relationship between development of empathy skills and students' startups, $b=0.2150, \mathrm{p}<.005$.

2. At the mean value of experiential learning activities, there is a significant positive relationship between development of empathy skills and students' startups, $b=0.1450, \mathrm{p}<.005$.

3. When experiential learning activities are high, there is a non-significant positive relationship between development of empathy skills and students' startups, $b=0.750, \mathrm{p}>.005$.

\section{Discussion of Findings}

Findings from the test of hypothesis revealed that experiential learning moderates the relationship between empathy and students' start-ups. Geiger and Oranburg (2018) argued that a business will fail when the entrepreneurs are less connected to their customer's emotions. In the same vein Popescul (2017) suggests that empathy motivates entrepreneurs to exhibit the successful entrepreneurial characteristics such as creativity and the ability to identify opportunities around their environment. Similarly, Nelson, Malkoc and Shiv (2017) suggest that an entrepreneur is expected to be aware of the needs of their customers, which motivates them to provide goods and services that their customers need. However, the uniqueness of this research is the influence experiential learning. This has implications for the curriculum contents of entrepreneurship courses which should focus on the process of learning the skills and mind-sets of entrepreneurs. As earlier stated and as shown from the results of the analysis, empathy is a key skill for entrepreneurs hence teaching empathy is a positive future action in expanding the scope of contents of an entrepreneurship program.

Another unique contribution of this study is that the moderation analysis showed that empathy fosters student start-ups at low and moderate levels of experiential learning activities. This aligns with the work of Piercy and Nigel (2011) and Bedawy (2017), suggesting that high levels of experiential learning activities in teaching empathy without a bit of theoretical instructions that provide students the opportunities to critically reflect on their learning experiences may be detrimental to the learning process.

\section{Conclusions and Implications}

Although extant research has attempted to examine various antecedents of students' start-ups in the university context, the specific link between empathy experiential learning and business start-ups among university students has not been extensively discussed in the literature. Therefore, based on the findings of this study it implies that if students are taught empathy with experiential approaches, it can may increase the propensity for business start-ups. The real reason why most start-ups fail is because they fail to understand their customers. They fail to feel what their consumers feel. Empathy is the factor which is the bridge to revenue and business scale up which encourages start up owners to understand customers more deeply. Therefore, university managers and other stakeholders may expand the curriculum of entrepreneurship training and education regimes to cover the development of empathy as an entrepreneurial skill. It is important to state that empathy is an entrepreneurial skill that can be developed hence, teaching empathy as a theme targeted at the creation of creative start-ups is considered favourable in this regard

\section{Suggestions for Further Research}

i). In order to confirm the relationships established in this report, the quantitative component of this research was a cross-sectional survey data collection process, other studies could be done using a longitudinal data collection technique.

ii). As quantitative data collection method, copies of the questionnaire have been used. Further studies could triangulate quantitative data collection process with in-depth interviews to enrich the process of collecting information.

iii). In this study, four dimensions of experiential learning and three dimensions each for empathy and student start-ups were identified. Other aspects and components of the above constructs could be considered in further research

\section{Conflict of Interest}

The authors declare that there is no conflict of interest

\section{Acknowledgments}

The authors would like to note that Covenant 
University sponsored this research work in its entirety.

\section{REFERENCES}

[1] Al-Husseini, S., \& Elbeltagi, I. (2018). The role of knowledge sharing in enhancing innovation: A comparative study of public and private higher education institutions in Iraq. Innovations in Education and Teaching International, 55(1), 23-33.

[2] Arasti, Z., Falavarjani, M.K., \& Imanipour, N. (2012). A Study of Teaching Methods In Entrepreneurship Education For Graduate Students. Journal of Higher Education Studies, 2(1): 2-10.

[3] Arenius, P. \& De Clercq, D. (2005) A Network - Based Approach on Opportunity Recognition. Small Business Economics, 24(6): 249-265.

[4] Armstrong, S. \& Mahmud, A. (2008): Experiential Learning and the Acquisition of Managerial Tacit Knowledge. Academy of Management Journal, 7(2):189-208.

[5] Becker, A., Knyphausen-Aufseß, D. Z., \& Brem, A. (2015). Beyond traditional developmental models: a fresh perspective on entrepreneurial new venture creation. International Journal of Entrepreneurial Venturing, 7(2), 152-172.

[6] Bedawy, R. (2017). Experiential Learning for Supporting Learning Effectiveness in Business Education: A Case Study from Egypt. International Journal of Business and Management. 12. 159. 10.5539/ijbm.v12n5p159.

[7] Berner, H. (2016). Are Ethnic Entrepreneurs Social Innovators? Turkish Migrant Entrepreneurs in Salzburg. BORDER CROSSING, 6(2), pp.363-371.

[8] Boahin, P., \& Hofman, W.A. (2012). Implementation of innovations in higher education: The case of competency based training in Ghana. Innovations in Education and Teaching International, 49(3), 283-293.

[9] Brinckmann, J. Grichnik, D. \& Kapsa, D. (2010). Should Entrepreneurs Plan or Just Storm The Castle? A Meta-Analysis on Contextual Factors Impacting Business Planning Performance Relationship in Small Firms. Journal of Small Business Venturing, 25: 24-40.

[10] Canziani, B., Welsh, D.H.B., Hsieh, Y.J., \& Tullar, W. (2015) What Pedagogical Methods Impact Students' Entrepreneurial Propensity? Journal of Small Business Strategy, 25(2): 97-113.

[11] Cassar, G. (2004), "The Financing of Business Start-Ups", Journal of Business Venturing, 19(2): 261-283.

[12] Castrogiovanni, G.1 (996). Prestartup Planning and the Survival of New Small Businesses. Theoretical Linkages Journal of Management, 22(6):801-822.

[13] Chandra, Y. (2017), 'Social entrepreneurship as emancipatory work', Journal of Business Venturing, 32 (6), $657-73$.

[14] Cid-Sillero, S., Santiago-Ramajo, S., \& Martín-Lobo, M. P. (2018). Relation between Executive Functions and Empathy and Their Influence on Academic Performance in Students of Basic Vocational Training. Electronic Journal of Research in Educational Psychology, 16(46), 517- 536.

[15] Cole, R \& Tatyana S (2014), "Debt Financing, Survival, and Growth of Start-up Firms", Annual Meetings of the Financial Management Association, Nashville, TN USA. Https://www.researchgate.net/.../266615427

[16] Costin, Y., O’Brien, M., \& Slattery, D. (2018). Using Simulation to Develop Entrepreneurial International Journal of Teaching and Learning in Higher Education Skills and Mind- Set: An Exploratory Case Study., 30(1), 136-145.

[17] Damodaran, Aswath. (2009), "Valuing Young, Start-up and Growth Companies: Estimation Issues and Valuing Challenges", Stern School of Business, New York University.

[18] Daniel, A. D. (2016). Fostering an entrepreneurial mindset by using a design thinking approach in entrepreneurship education. Industry and Higher Education, 30(3), 215-223.

[19] Danish Agency for Science Technology \& Innovation (2016). Entrepreneurship and Startup Activities at Indian Higher Institutions, IDCK Analysis, 3:1-37.

[20] Davis, M.H., 2015. Empathy and prosocial behavior. In: Schroeder, D.A., Graziano, W.G. (Eds.), The Oxford Handbook of Prosocial Behavior. Oxford University Press, New York, NY. 282-306.

[21] Davis, M.H., 2015. Empathy and prosocial behavior. In: Schroeder, D.A., Graziano, W.G. (Eds.), The Oxford Handbook of Prosocial Behavior. Oxford University Press, New York, NY 282-306.

[22] Dawson, A. (2016). Global university entrepreneurial spirit students' survey (GUESSS). Student entrepreneurship at the John Molson School of Business. Montreal, Canada, 2016 Report.

[23] Dees, J.G., (2012). A tale of two cultures: charity, problem solving, and the future of social entrepreneurship. Journal Business Ethics 111, 321-334

[24] Dees, J.G., 2012. A tale of two cultures: charity, problem solving, and the future of social entrepreneurship. J. Bus. Ethics 111, 321-334

[25] Delmar, F. \& Shane, S. (2003). Does Business Planning Facilitate the Development of New Ventures? Strategic Management Journal, 18(3): 301-33.

[26] Dimov, D., (2010). Nascent entrepreneurs and venture emergence: opportunity confidence, human capital, and early planning. Journal Management Studies. 47 (6), 11231153.

[27] Doherty, R. (2018). Mick Horton: 'Empathy for your patients is the most important trait a GDP needs'. BDJ, 225(1), .11-13.

[28] Fairbairn GJ. (2002). Ethics, Empathy and Storytelling in Professional Development. Learning in Health and Social Care, 1:22-32

[29] Farahbod, F. (2014). The relationship between trait emotional intelligence and entrepreneurship attitudes and intentions. Journal of Public Administration and Policy 
Research, 5(3), 79-85. https://doi.org/10.5897/jpapr2013.0 242

[30] Felten, P., Gilchrist, L. Z., \& Darby, A. (2006). Emotion and learning: Feeling our way toward a new theory of reflection in service learning. Michigan Journal of Community Service Learning, 12, 38-46.

[31] Fontinelle, A. (2017). What exactly is a start-up? Investopedia. Retrieved from https://www.investopedia.co $\mathrm{m} /$ ask/answers/12/what-is-a-startup.asp

[32] Geiger, M. and Oranburg, S. (2018). Female entrepreneurs and equity crowd funding in the US: Receiving less when asking for more. Journal of Business Venturing Insights, 10, p.e00099.

[33] Ghenea M. The Legally Universe Bucharest 2011. International Journal of Entrepreneurial Behavior \& Research, 23(5), 839-841.

[34] Gibb, A.A. (2005) 'The Future of Entrepreneurship Education. Determining the Basis for Coherent Policy And Practice, Chapter 2 In Kryo, P And Carrier, C. The Dynamics of Learning Entrepreneurship in a Cross-Cultural University Context. University of Tampere Research Centre for Vocational and Professional Education, 44-68.

[35] Grando, N. (2016). What Are the Characteristics of a Start-up company? Quora. Retrieved from https://www.quora.com/What-are-the-characteristics-of-a-st artup-company

[36] Halpern J. (2007). Empathy and Patient-Physician Conflicts. Society of General Internal Medicine,22:696-700

[37] He, C. (2017). Professor Bruce W. Lytle: let the talented people exhibit their ideas without inhibiting them, taking the advantages of the people around you-the key for collaboration. ASVIDE, 4, 426-426.

[38] Helle, L., Tynjälä, P., \& Olkinuora, E. (2006). Project-based learning in post-secondary education - theory, practice, and rubber sling shots. Higher Education, 51(2), 287-314.

[39] Helle, L., Tynjälä, P., Olkinuora, E., \& Lonka, K. (2007). 'Ain't nothing like the real thing.' Motivation and study processes on a work-based project course in information systems design. British Journal of Educational Psychology, 77(2), 397-411.

[40] Honig, B. \& Karlsson, T. (2004). Institutional Forces and Written Business Plan. Journal of Management, 30(1):29-48.

[41] Hormozi, A.M, Sutton, G.G, Mcminn, R.D \& Lucio, W. (2002). Business Plans for New or Small Businesses: Paving the Path to Successie, Management Decision, 40(7/8): 755763.

[42] Ickes W (ed) (1997). Empathic Accuracy. Guilford Press, New York

[43] Kassean, H., Vanevenhoven, J., Liguori, E., \& Winkel, D. E. (2015). Entrepreneurship education: A need for reflection, real-world experience and action. International Journal of Entrepreneurial Behavior \& Research, 21(5), 690-708

[44] Keen S (2007). Empathy and the Novel. Oxford University Press

[45] Kenton, W. (2018). Start-up. Investopedia. Retrieved from https://www.investopedia.com/terms/s/startup.asp

[46] Khajeheian, D. (2013). New Venture Creation in Social Media Platform; Towards a Framework for Media Entrepreneurship. In Handbook of Social Media Management 125-142. Springer Berlin Heidelberg.

[47] Knowles, M., Holton, E. And Swanson, R. (2011). The Adult Learner: The Definitive Classic in Adult Education and Human Resource Development. Elsevier Inc., Burlignton, MA. ISBN: 9780750678377.

[48] Knowles, M., Holton, E. And Swanson, R. (2011).The Adult Learner: The Definitive Classic in Adult Education and Human Resource Development. Elsevier Inc., Burlignton, MA. ISBN: 9780750678377.

[49] Korte, R., Smith, K. A., \& Li, C. Q. (2018). The Role of Empathy in Entrepreneurship: A Core Competency of the Entrepreneurial Mindset. Advances in Engineering Education, 7(1), 1-10.

[50] Kutlu, A. \& Coskun, L.. (2014). The Role of Empathy in the Learning Process and Its Fruitful Outcomes: A Comparative Study. Journal of Educational and Social Research. 10.5901/jesr.2014.v4n2p203.

[51] Long, B. (2010), 7 Tips for Idea Generation for Start - ups, Spring - Singapore. Http://www.sgentrepreneurs.com.

[52] Malach, S.E., \& Malach, R.L. (2014). Start Your Own Business Assignment in the Context of Experiential Entrepreneurship Education. Journal of Higher Education Outreach and Engagement, 18(1): 169.

[53] Mayer, J., Roberts, R., \&Barsade, S. (2008). Human Abilities: Emotional Intelligence. Annual Review of Psychology, 59, 507-536.

[54] Morais, R. J. (2001) Analytical Ideation: Power Brainstorming, Brand Week, 42(3):22-23. Baker, W.H, Addams, L.H \& Davis, B (1993). Business Planning in Successful Small Firms. Long Range Planning, 26(6): 82-88.

[55] Morris M., Shirokova G., \& Tsukanova T. (2015). Student entrepreneurship and the university ecosystem: A multi-country empirical exploration. European Journal of International Management, 65-85

[56] Nabi, G., Holden, R., \& Walmsley, A. (2006). Graduate Career-Making and Business Start- Up: A Literature Review. Education+Training, 48(5): 373-385.

[57] Nabi, G., Liñán, F., Fayolle, A., Krueger, N., \& Walmsley, A. (2017). The impact of entrepreneurship education in higher education: A systematic review and research agenda. Academy of Management Learning \& Education, 16(2), 277-299.

[58] Neck, H. \& Greene, P. (2011). Entrepreneurship education: Known worlds and new frontiers. Journal of Small Business Management, 49(1): 55-70.

[59] Neck, H. \& Greene, P. (2011). Entrepreneurship education: Known worlds and new frontiers. Journal of Small Business Management, 49(1): 55-70.

[60] Nelson, N., Malkoc, S. and Shiv, B. (2017). Emotions Know Best: The Advantage of Emotional versus Cognitive Responses to Failure. Journal of Behavioral Decision 
Making, 31(1), 40-51.

[61] Nielsen, S. \& Stovang, P.. (2015). DesUni: university entrepreneurship education through design thinking. Education + Training. 57. 977-991. 10.1108/ET-09-2014-0121.

[62] O’Boyle, E. H., Humphrey, R. H., Pollack, J. M., Hawver, T. H., \& Story, P. A. (2011). The relation between emotional intelligence and job performance: A meta-analysis. Journal of Organizational Behavior, 32, 788-818.

[63] Ogbari, M.E., Oke, A.O., Ibukunoluwa, A.A., Ajagbe, M.A., Ologbo, A.C. (2016) Entrepreneurship and Business Ethics: Implications on Corporate Performance. International Journal of Economics and Financial Issues 6(3), 50-58.

[64] Olokundun, M.A., Ibidunni, A.S., Peter, F., Amaihian, A.B., \& Ogbari, M. (2017). Entrepreneurship Educator's Competence on University Students' Commitment To Learning And Business Plan Writing. Academy of Strategic Management Journal, 16(2): 1-10

[65] Olokundun, M.A., Moses, C.L., Iyiola, O.O., Ibidunni, A.S., Amaihian, A,B., \& Peter, F., (2017). Perceptions of Students on Entrepreneurship Curriculum Contents and Openmindedness: Implications for Business Idea Generation of Nigerian University Students. Academy of Entrepreneurship Management 23(2), 1-10

[66] Olorundare, A.S., \& Kayode, D.J. (2014).Entrepreneurship Education in Nigerian Universities: A Tool for National Transformation, Asia Pacific Journal of Educators and Education, 29: 155-175.

[67] Ooi, Y.K., \& Ahmad, S. (2012). A Study among University Students in Business Start-Ups in Malaysia: Motivations and Obstacles to Become Entrepreneurs. International Journal of Business and Social Science, 3(19), 181-192.

[68] Pam, W.B. (2013). Opportunity Recognition And Business Idea Generation as a Foundation for Entrepreneurial Business in Central Nigeria. International Journal of Business and Social Sciences, 4 (17): 238-245.

[69] Penaluna K., Penaluna A., Jones C. (2012), 'The Context of Enterprise Education: Insights into Current Practice', Industry and Higher Education, 26(3):163-175.

[70] Perry, S.C (2001). The Relationship Between Written Business Plans and The Failure of Small Businesses In The US $^{e e}$, Journal of Small Business Management, 39(3): 201-208.

[71] Piercy, N.,\& Nigel,C.(2011).Experiential learning in the international classroom: Supporting learning effectiveness and Integration. International Journal of Management Education, (2), 25-35.https://doi.org/10.3794/ijme.92.313

[72] Piperopoulos, P., \& Dimov, D. (2014). Burst Bubbles or Build Steam? Entrepreneurship Education, Entrepreneurial Self-Efficacy, and Entrepreneurial Intentions. Journal of Small Business Management, DOI:10.1111/jsbm.12116.

[73] Pittaway, L. \& Edwards, C. (2012). Assessment: Examining practice in entrepreneurship education. Education + Training. 54. 10.1108/00400911211274882.

[74] Popescul, L. (2017). Entrepreneurship. The Road to Ideas to Opportunities and Business Success Entrepreneurship. The Road to Ideas to Opportunities and Business Success
[75] Prandelli, E., Pasquini, M., \& Verona, G., 2016. In user's shoes: an experimental design on the role of perspective taking in discovering entrepreneurial opportunities. Journal of Business. Venture. 31 (3), 287-301

[76] Purcarea, I. (2012). Entrepreneurship and Higher Education. An Outlook on Some Best Practices in Entrepreneurship Education. Romanian Distribution Committee Magazine, 3(4): 20-26.

[77] Saeid, K., Harm J.A., Biemans, T., Lans, M.A. \& Martin, M. (2014): Fostering Students' Competence In Identifying Business Opportunities in Entrepreneurship Education, Innovations in Education and Teaching International, DOI:10.1080/14703297.2014.993419.

[78] Salamzadeh, A. (2015b). New Venture Creation: Controversial Perspectives and Theories. Economic Analysis, 48(3/4), 101-109.

[79] Saukkonen J., (2017). From a Student of Startup Business to a Startup Employee or Entrepreneur : Study on Career Narratives of Students in Entrepreneurial Programs in a University., Macrothink Institute. doi:10.5296/jei.v3i1.1111 7

[80] Shabangu, S. (2014). The Importance of Start-up Companies for Economic Development. Linked in. Retrieved from https://www.linkedin.com/pulse/2014112208442877551011-the-importance-of-startup-companies-for-econo mic-development

[81] Shirokova, G. Osiyevskyy, O. Bogatyreva, K. (2015) Exploring the Intention-Behavior Link In Student Entrepreneurship: Moderating Effects Of Individual And Environmental Characteristics European Management Journal 30(1), 14

[82] Sophie, B. \& Elisa Alt (2018) Fwwling capable and valued: A prosocial perspective on the link between empathy and social entrepreneurial intentions. Journal of business venturing 33: 333-350.

[83] Stevens, D. \& Cooper, J. (2009).Journal Keeping: How to use Reflective Writing for Learning, Teaching, Professional insight and positive change. Sterling, VA: Stylus Publications.

[84] Svinicki, M. D., \& McKeachie, W. J. (2014). McKeachie's teaching tips: Strategies, research, and theory for college and university teachers (14th edition). Belmont, CA: Wadsworth Cengage Learning.

[85] Ubogu, R.E. (2013). Quality Assurance in Entrepreneurship Education: A Strategic Option for National Development. Association of Business Educators Nigeria, 3(1): 240-245.

[86] Weber, M. (2015). Developing what customers really need: involving customers in innovation. IEEE Engineering Management Review, 43(2),34-44.

[87] White, R., Hertz, G., \& D'Souza, R. (2011). Teaching a Craft - Enhancing Entrepreneurship Pedagogy. Small Business Institute Journal, 7(2): 1-14.

[88] Zapeda, P.G. (2013). Exploring effective teaching approaches in university entrepreneurship education, Portland State University.

[89] Zapeda, P.G. (2013). Exploring effective teaching 
approaches in university entrepreneurship education, Portland State University.

[90] Zhou, H., Tao, H., Zhong, C., \& Wang, L. (2012).
Entrepreneurship Quality of College Students Related to Entrepreneurial Education. Energy Procedia 17(1): 1907 1913. 